\title{
ANDREY DEVYATKOV, MARCIN KOSIENKOWSKI Testing Pluralism: Transnistria in the Light of the 2011 Presidential Elections
}

\begin{abstract}
The article describes new political developments in Transnistria, a quasi-state that has been outside of Moldovan control since 1992. Transnistria has gone through the process of gradual pluralisation over the last few years. This fact was fully manifested during the December 2011 presidential elections when due to several factors examined in this paper, Igor Smirnov - the Transnistrian, authoritarian and eternal leader - unexpectedly failed to be re-elected for his fifth term, and was replaced by Yevgeniy Shevchuk. The authors note that Transnistria's pluralisation positively affects the process of the Transnistrian conflict settlement. However, they have also come to the conclusion that prospects offurther democratisation of the quasi-state are rather nebulous.
\end{abstract}

Keywords: Transnistria, democratisation, quasi-state, Transnistrian conflict, Moldova

\section{INTRODUCTION}

A dynamic democratisation process like the one in the Middle East is now under way in the post-Soviet space. But the "Arab spring" has already brought out some negative consequences that are likely to provoke an "Arab autumn". Great

1 Andrey Devyatkov, PhD, is a Senior Lecturer at the Institute of Human Sciences of Tyumen State University and a recent visiting fellow at New Europe College, Bucharest, and the German Institute for International and Security Policy, Berlin. His research focuses on the Transnistrian issue, as well as Russian and Romanian foreign policies towards Moldova. E-mail: devyatkovav@ gmail.com.

Marcin Kosienkowski, PhD, is an assistant professor at the Institute of Political Science and International Affairs of the John Paul II Catholic University of Lublin, Poland. His research focuses on the post-Soviet area, mainly Moldova and its breakaway region of Transnistria. Kosienkowski is the author of The Pridnestrovian Moldavian Republic: Survival Determinants [Polish] (Wydawnictwo Adam Marszałek, 2010) and Continuity and Change in Transnistria's Foreign Policy after the 2011 Presidential Elections (The Catholic University of Lublin Publishing House, 2012), and co-editor (with William Schreiber) and author of Moldova: Arena of International Influences (Lexington Books, 2012). E-mail: kosienkowski@kul.pl. 
challenges for Russian, South Ossetian and Transnistrian societies, which have faced dramatic elections in 2011 and as a result have stirred up quite a strong opposition, are evident. The first challenge is to go through democratisation without systemic destabilisation, ethnic hatred and civil war.

This article considers the problems of regime evolution in Transnistria, a region on the left bank of the Dniester with its political centre in Tiraspol. Officially the territory belongs to the Republic of Moldova, but in fact, it has been an unrecognised quasi-state since 1992. Transnistria has gone through the process of gradual pluralisation over the last few years. This fact was manifested during the December 2011 presidential elections, when the second round of the elections were won by an opposition candidate, Yevgeniy Shevchuk. Unlike his latest rival Anatoliy Kaminskiy, he was not supported by Russia, the main external sponsor of the Transnistrian de facto statehood, and was rather on the fringes of Transnistrian politics. However, he swept the elections with an overwhelming majority of votes - approximately $74 \%$. The Transnistrian leader Igor Smirnov, who had been in power for 20 years and had managed to establish the authoritarian system, was unexpectedly defeated and expelled from the presidential run after the first round of the elections. It is important to mention here that although he was quite reluctant to accept his defeat, he finally did and left office.

The question under consideration is why the regime of Igor Smirnov, who had been so likely to be re-elected, collapsed so quickly, and what are today's prospects of the Transnistrian political system development in terms of democratisation and the Transnistrian conflict settlement. Researchers such as Nicu Popescu (2006) and Oleh Protsyk (2009), traditionally connect the issues of Transnistrian authoritarianism and conflict settlement, stating that it is mainly the authoritarian political system that has made it possible to consolidate the Transnistrian de facto statehood. This paper tends to analyse the Transnistrian political system as an independent variable, apart from the issue of conflict settlement. Nevertheless, the article underlines the idea that a more democratic political system is more apt to find solutions within the process of conflict settlement, which would meet the needs of social and economic actors. These needs seem to be more complicated than was officially presented during Smirnov's era. It is also assumed that Tiraspol's position is very important for the resolution of the Transnistrian conflict, and that the two conflicting parties - Moldova and Transnistria - should first resolve their controversies.

The first section of the article expands on the characteristics of Smirnov's authoritarian regime, i.e. its depoliticisation and corporativisation strategy, and 
its subsequent degradation to populist autocracy. The second section describes the factors of political change which brought Smirnov's regime to the ground, such as the revulsion of public sentiments, the institutionalisation of the oppositional forces and the external pressure from Russia. Later on, prospects of the further democratisation of the Transnistrian political system and the impact of Transnistria's pluralisation on the Transnistrian conflict settlement are analysed. ${ }^{2}$

\section{THE MAIN FEATURES OF SMIRNOV'S REGIME OR HOW THE STEEL WAS TEMPERED}

Twenty years of Transnistrian history have passed away under a state of emergency. Even though it had some objective preconditions, the evolution of the political regime towards autocracy was also rooted in the intentions of the ruling elite and society's willingness to support such a political contract with the authorities.

Transnistria separated from Moldova because of a political conflict. In June-July 1992 the conflict spilled over into a bloody skirmish around Bendery (Memorial 1992). During Soviet times both banks of the Dniester were included into the Moldavian Socialist Republic, which was only established in 1940 (after the Soviet Union had got historical Bessarabia, or the right bank, back from Romania) and had no potential to merge into a stable political construction able to overcome the post-Soviet turbulence. The Transnistrian conflict was not ethnic by nature, because the level of ethnic mobilisation in both Moldova and Transnistria during the conflict escalation was very low (Crowther 1991, p. 153). However, Chisinau and Tiraspol broke off communication after the attempts of radical nationalistic forces in Chisinau to promote a "national (Moldovan and for some of them - Romanian) revival", while in Tiraspol, a more Soviet, internationalised, and also Russified landscape dominated. The language issue became a stumbling block of the confrontation: Chisinau decided to use the Latin alphabet for the Moldovan language while Transnistria opposed such a reform, claiming that it pushed Moldova more and more towards Romania. Nevertheless, unlike the

2 See also a very interesting paper by Protsyk (2012) describing the character of the Transnistrian political regime. Although it coincides thematically with the present paper, it offers little information about the latest presidential elections in Transnistria and prospects of further democratisation of Transnistria, and nothing about developments related to the Transnistrian conflict settlement after Shevchuk rose to power. 
situations in Azerbaijan and Georgia, the Transnistrian conflict stopped being a military threat immediately after the cease-fire was signed in July 1992. But the political confrontation of the two banks of the Dniester was not yet exhausted.

Despite the changes of government in Chisinau, its general approach to the conflict settlement remained the same. It was based on the case of Gagauzia, another region of Moldova which preferred to end the confrontation with Chisinau by obtaining autonomy status in 1994. However, this autonomy pretty soon became delusive, predominantly because of the fragile democracy in Moldova, which still has some ethnocratic features. Additionally, since 2001 the Moldovan government has tried to undermine the economic basis of the Transnistrian de facto statehood and integrate it into its own customs space, partially achieving these goals in 2006 with the help of the European Union and Ukraine, which has led to a series of information wars and mutual economic restrictions. After some time a new perception of the two banks of the Dniester became prevailing: they were seen as different political subjects following in different geopolitical, socioeconomic and mental tracks. The citizens of Transnistria had many reasons to believe the state-building project in their region to be more successful than the one in Moldova. The latter was plunged into economic degradation and political instability. The Moldovan economy received shock therapy from market reforms with the subsequent diminishing of state resources, while the Transnistrian economic system still rested upon directive planning throughout the whole of the $1990 \mathrm{os}$. As a result, Transnistrian pensioners, workers and officials received a regular allowance from the state, unlike their Moldovan counterparts.

The elite which had been in power in Tiraspol during the military confrontation with Moldova and revealed enough organisational and political skills, received what amounted to an exclusive power mandate from the Transnistrians. Because of immature civic institutions, the post-Soviet mental and political inertia and the socioeconomic breakdown, the people of Transnistria were mostly focused on bread-and-butter issues. Thus, the ruling elite was handed wonderful opportunities to gain the upper hand over the country. A very charismatic leader Igor Smirnov - emerged and a personalistic authoritative regime started to be established around him.

Like any other authoritarian regime, Smirnov's strategy was based on depoliticisation. Security was declared to be a social priority. It was interpreted through the prism of neo-realist logic which determines that security is exceptionally about survival (Buzan et al. 1998, p. 1). So the local elite positioned themselves as indispensable defenders of Transnistrian independence; while their opponents were presented as the breakers of the societal consensus. Even 
in his autobiography, Smirnov (2005, p. 58) used quite strong language to talk about Andrey Safonov, a member of the opposition, political scientist and rather patriotic public figure. Therefore, a large part of the Transnistrian population were in fact excluded from politics. The people were offered to participate in regular referendums and elections which were predominantly non-competitive, and as a result, the authorities received formal confirmation of their political course. Other candidates simply did not get the possibility to become a sustainable alternative because they were administratively pressured, an informational blockade was imposed on them, and the adherents of the president harshly criticised them in propagandistic campaigns (Freedom House 2001).

Smirnov's treatment of political parties and the political process in general also reveals his depoliticisation strategy. "Parties split the society, either deliberately or not... [in order to] corruptibly solve their own problems forgetting about the state", Smirnov said (Viktorov 2011). In Smirnov's times, even if political institutions were called "parties", it meant nothing. They were just movements to provide some degree of public inclusion into politics, but, in fact, such institutions had very limited influence on decision-making. The conditions were not favourable for these quasi-parties; moreover, they were not able to participate in the formation of the government. Transnistria also did not have a prime-minister; the president personally headed the cabinet. It was a vertical executive of "manual control", with the president and vice-president as the key figures.

Nevertheless, the Transnistrian regime also had some corporatist features. It made it possible for the regime to adapt to the fact that up to 1992 there were lots of highly politicised social groups in the regional political landscape. These groups emerged in those distempered times when Transnistria had to set up its state structure from the ground up (because during the Soviet period the territory located on the left bank of Dniester had no autonomy within the Moldavian Soviet Socialist Republic, unlike Abkhazia, South Ossetia and Nagorno-Karabakh within their Soviet republics). Thus, before power fell into Smirnov's hands, it had been possible for active and institutionalised social groups to bring forward some political requests. During summer 1992, right after the armed conflict had been done away with, the regime introduced a strategy which was meant to incorporate all politicised social groups, depriving them of any autonomy, but letting them participate in the process of the redistribution of budget resources, therefore granting them some room within the quasi-state organism. The security forces, national organisations, bureaucracy, employees and management at state factories should also be mentioned in this context. 
With respect to the security forces, it should be noted that it was not the regular army, but various paramilitary organisations (such as the Republican Guard, Cossacks etc.), the police, the public prosecution and the almighty Transnistrian Ministry of State Security who were the main supporters of the regime, favouring a high level of societal militarisation. Organisations of veterans (of the 1992 war against Moldova and the 1979-1989 war in Afghanistan) affiliated to the aforementioned institutions also belonged to this group. Militarisation of society allowed security institutions to achieve their own corporate goals. This fact can be illustrated through the example of Sheriff, the biggest private financial group in Transnistria. According to his official biography, ${ }^{3}$ Sheriff's director, Ilya Kazmaly, like many of his other colleagues, came from the top echelon of the Transnistrian Ministry of Internal Affairs. The company's very name shows the roots of this powerful financial and industrial conglomerate.

As for national organisations, the Moldovan Union can be named as the most important actor. This Union did not share the radical position of Moldovan nationalism in its post-Soviet variant. And after Smirnov neutralised its head, Vasiliy Yakovlev, who openly dared to challenge the president's power by accusing him of "giving up the republic" through negotiations with Moldova, the Union turned to be one of the organisations that provided massive support to the presidential policy from "below". But the Union can hardly be considered as representing the interests of Transnistrian Moldovans who, according to some facts, never favoured the split of the Moldavian SSR, and at the same time opposed some linguistic and political decisions made unilaterally by Chisinau at the beginning of the 1990s. For example, the Pridnestrovian Moldavian Republic (Transnistria's official name) was only proclaimed in its contemporary boundaries after the local authorities in rural areas mainly inhabited by Moldovans, who remained loyal to the Moldovan government, had been overthrown (ICG 2003, p. 3). This is the reason why Moldovans could be treated as a group excluded from the political process, despite the fact that the republic was established as a multinational state with three official languages, including Moldovan (but written in Cyrillic as in the Moldavian SSR, not in Latin adopted in Moldova in 1989) (Protsyk 2009, pp. 257-281). It is also important to point out that Transnistrian Moldovans felt (for historical reasons) quite indifferent about "national revival", which agitated Moldovans on the right bank of the Dniester. Thus, the regime managed to cope with this challenge. Nevertheless, the under-representation of Transnistrian Moldovans, who make up one third of the Transnistrian population,

3 Avaible at: http://vspmr.org/Deputy/?ID=63, accessed 4 January 2012. 
was openly articulated as a problem during the official inauguration of the newly elected president in December 2011. Grigoriy Marakutsa, the first and long-standing speaker of the Transnistrian parliament between 1990-2005 and one of the most loyal representatives of the Transnistrian Moldovan community, overtly criticised Smirnov for not supporting Moldovan culture and language sufficiently while Russian language was becoming more and more dominant. ${ }^{4}$ This is just one example of how the corporate institutions could imitate the representation of interests.

The third group was composed of management and workers of big factories, predominantly state-owned during the 1980s-1990s. The high level of the industrialisation in the region during the Soviet period (unlike agrarian Bessarabia) made this social group particularly active and influential, even after the collapse of the Soviet Union. Smirnov himself had been the head of the Elektromash factory and had been effectively promoted to politics by his colleagues (usually called "red directors"). Initially, workers and managers feared ethnolinguistic discrimination practised to some extent on the right bank of the Dniester (Obosnovaniye sozdaniya 1999, pp. 117-121). Moreover, for the management to be loyal to the authorities was a guarantee of having access to the budget resources. Workers of these factories received small but regular salaries which mainly provided their living during the economic chaos of the 1990 os and the domination of the command economy. The same kind of motivation was used for the representatives of the bureaucratic apparatus and the professional intelligentsia. Many experts, lecturers and cultural workers closely connected their work with the "Transnistrian idea".

State structures and economic actors in Transnistria also profiteered from smuggling. This point is rather speculative and was used extensively within the Moldovan and European discourse to blame the Transnistrian statehood for its "true (criminal) foundations". Nevertheless, smuggling did take place, maybe even with weapons and drugs, but predominantly and extensively with goods like cigarettes, gasoline, and common things for every "grey zone" with the status such as Transnistria's. Furthermore, Transnistria is located close to the port of Odessa, a well-known Ukrainian paradise for smugglers.

In the middle of the 2ooos it became clear that the Transnistrian regime had degraded to a populist autocracy. The authorities were becoming more and more ineffective in governance: the official discourse and governance practices were

4 See "Polnaya versiya inauguratsii prezidenta PMR Yevgeniya Shevchuka", available at: http:// www.youtube.com/watch?v=mktmdKguTok\&feature=related, accessed 4 January 2012. 
not directed at innovation and useful reforms, but primarily focused on the idea of how to redistribute Russian financial assistance that had been coming to the region in abundance since 2006. Additionally, Transnistria has stopped paying back for Russian gas since 2007-2008, and its gas debts had amounted to the astronomical sum of about 3 billion dollars. ${ }^{5}$ Instead of being made to Gazprom, payments were simply reallocated to the Transnistrian budget in order to cover its deficit. Nevertheless, it did not prevent living standards in the region from decreasing.

Complete independence alone was officially declared the best way to resolve the frozen conflict. The thesis about the "Transnistrian nation" also began to be actively promoted (Troebst 2003). The authorities had to invest a lot in this idea because, from a historical perspective, Transnistria was a political community which had only appeared in 1990, and was internally dispersed as far as it consisted of various ethnic groups (first of all, Moldovans, Ukrainians and Russians). None of them were able to exclusively promote state-building. After the state structures failed to meet the people's basic needs, the authorities created the "Transnistrian idea", founded on a negative basis (in regard to the Republic of Moldova), their own resource for gaining legitimacy. Statements about the "Romanising" of Moldova became very common in every political speech; the authorities used this to avoid talking to society about many of its real problems such as dirty streets, broken roads, depopulation and deindustrialisation of the region, etc. Every now and then, Tiraspol tended to cut off all contacts with Chisinau despite all the economic and social damage it brought, and declared Moldova to be the main source of Transnistria's problems. The Transnistrian case seemed to fit all the characteristics of a "racketeer state" given by Dov Lynch (2004, pp. 91-102).

External factors - first of all Russian influence - also played into the hands of the emerging authoritarianism in Tiraspol. Russia, the key external sponsor of the Transnistrian de facto statehood, treated Transnistria mainly as the leverage to influence the whole of Moldova. From time to time, Moscow tried to involve the latter in integration projects such as the Russia-Belarus Union. In the European context the deployment of peacekeepers and soldiers in Transnistria, whose formal mission was to guard post-Soviet ammunition depots, was a guarantee against the deepening of Moldovan and, to some extent, Ukrainian partnership with NATO. This geopolitical agenda coincided with the intention of Smirnov's regime to move away from Moldova; although Transnistrians have always been

5 “Transnistria's gas debt skyrockets", $R B C, 17$ October 2011, available at: http://www.rbcnews. com/free/20111017154503.shtml, accessed 4 January 2012. 
critical about Russia's instrumental approach and Moscow's unwillingness to recognise Transnistrian independence. Russia-Transnistria relationships only became worse when Russia tried to implement the cooperative approach towards the West and Moldova within the conflict settlement process. This happened, for example, in 2001-2002 when Russia was working to fulfil the terms specified in the Treaty on Conventional Forces in Europe. Nevertheless, the conflicts between Tiraspol and Moscow were rather an exception than a rule; Russia revived some Cold War practices providing support to Smirnov, as far as the latter was very likely to become Russia's partner in political confrontation with the West.

Under these conditions Smirnov managed to stay in power after the presidential elections in 2006 and was determined to do the same in 2011. But populist regimes always end in the same way, particularly when they are surrounded by countries (in Transnistria's case, Ukraine and Moldova) who actively participate in the process of Europeanisation. Populist regimes are either overthrown by force or swept away by elections.

\section{FACTORS OF PLURALISATION OR HOW THE STEEL WAS CORRODED}

Five factors behind political change in Transnistria, in other words its pluralisation, can be identified. They are as follows: the people's demand for change, the institutionalisation of the political opposition carried out by part of the economic elites, Russia's support for the opposition and pressure on Igor Smirnov, the lack of a threat against Transnistria from Moldova, and the existence of a politician associated with a true renewal, requested by Transnistrian citizens.

The basic factor of Transnistrian politics' pluralisation was increasing people's demands for economic, social and political changes in their homeland. Although Smirnov was still appreciated by many as the father of Transnistria, more and more people began to associate him with deep stagnation in all spheres of life, rampant corruption, and other negative phenomena. The population's need for change became obvious in the mid-2ooos and reached their highest point in the first round of the December 2011 presidential elections. The majority voted for Yevgeniy Shevchuk and Anatoliy Kaminskiy, who together got almost two-thirds of votes, leaving Smirnov out of the presidential run. It was no accident that Shevchuk and Kaminskiy were the leaders of the Vozrozhdeniye Pridnestrov'ya (Revival of Transnistria) public movement, and the Obnovleniye (Renewal) political party, respectively. The slogans of the candidates were also meaningful Shevchuk's "There will be order!" and "Change we need!", and Kaminskiy's "For 
a dignified life and the prosperity of the people" and "Good news for each family". Meanwhile Smirnov's catchphrase, "Transnistria is not for sale", was an element of old war rhetoric, this time picturing his political rivals, not Moldova, as traitors willing to destroy Transnistria's independence and, as usual, presenting Smirnov as its only defender.

It was chiefly the poor socioeconomic situation which made Transnistria's population start demanding change. The level of the quasi-state's living standards is one of the lowest in Europe with about 2,ooo dollars GDP per capita. Although Smirnov still attached great importance to keeping Soviet-style social and economic privileges, it was only really appreciated by pensioners, not by everyone. Moreover, people could hardly make ends meet. It is enough to say that under the harsh socioeconomic conditions many people decided to find a job abroad and left Transnistria. According to Transnistrian data, the population of the quasi-state shrank within 20 years by almost one-third from 750,00o in 1989 to 514,00o in $2011 ;^{6}$ other statistics were even more pessimistic. The poverty of Transnistria's ordinary citizens contrasted with the wealth of the authorities and businessmen linked to the political establishment, which fuelled people's discontent with the Smirnov regime, as well as with local elites on the whole.

Another factor urging many people's bids for change in their homeland was that they feared economic stagnation in Transnistria would not only prevent its development, but could also undermine its very existence. Furthermore, critics of the mismanagement of Smirnov's regime emerged extensively from within the Transnistrian elite, even among close adherents of Smirnov such as Grigoriy Marakutsa. ${ }^{7}$ He stated that Transnistria was losing its economic autonomy and perspectives for statehood due to the government's failures. ${ }^{8}$ To depict the scale of the crisis it is enough to say that a planned budget deficit for 2011 reached a record figure of $106 \%{ }^{9}$ (it was even initially up to $160 \%$ ). It can also be added that the steadily growing external gas debt amounted to about 3 billion dollars by the end of 2011, which statistically meant almost 6,0oo dollars per each Transnistrian inhabitant. The quasi-state was only able to survive due to Russia's support, which was overtly admitted even by Smirnov.

6 "Naseleniye Pridnestrov'ya sokrashchayetsya", Komsomol'skaya prawda, 31 October 2011, available at: http://kp.md/online/news/1009493/, accessed 2o December 2011.

7 Cf. Way (2011, p. 19).

8 Alltiras.com, 14 December 2009, available at: http://alltiras.com/conferences/2591marakutsa-grigoriy.html, accessed 5 January 2012.

9 “Zakon PMR № 242-Z-IV 'O respublikanskom byudzhete na 2011 god' ”, available at: http:// www.president.pmr-gov.org/zakon/?category=1\&id=1546, accessed 26 December 2011. 
The next factor which contributed to the pluralisation of Transnistrian internal politics was the institutionalisation of the political opposition in the 2000 . Admittedly, the opposition had existed in Transnistria since its appearance at the beginning of 199os, but due to countermeasures in the Smirnov regime it was dispersed, weak, and kept under the control of the authorities (Moshnyaga 2002, pp. 222-223). The breakthrough took place when a part of the economic elites grouped in Sheriff gained in strength and decided to challenge Smirnov's exclusive right for political power (Korobov \& Byanov 2006). Sheriff was set up by the Smirnov regime in 1993 to ensure the functioning of Transnistria on an economic level. Due to many privileges such as exemption from import duties or exclusive rights to trade in liquid fuels, alcohol and cigarettes, and involvement in shady external trade operations, Sheriff developed into one of Transnistria's biggest companies. It became the owner of a network of petrol stations and supermarkets, a sports complex, a football club, a television and telephone network, a bank, an advertising agency, a publishing house, and two major Transnistrian companies - Tirotex, a textile factory and KVINT, a distillery. At the beginning of the 21st century, the authorities and Sheriff drifted apart. Sheriff was unhappy about the fact that the Smirnov regime did not adequately take its interests into account during the privatisation of the Transnistrian economy, and that the authorities began to insist that the company should finance Transnistria's budget deficit. ${ }^{10}$ Sheriff also realised that it had much to lose economically from the authoritarian excesses of the Smirnov regime and the non-constructive position in the Transnistrian conflict settlement process (Popescu 2006, p. 13). This meant that the company's political activity was focused on its economic interests, which were either jeopardised or impeded in Smirnov's Transnistria. ${ }^{11}$ However, Vladimir Țesliuc, a Moldovan journalist, was right when he gave a broader explanation, saying that "the child grew up and willed to have more".

The political activity of Sheriff and institutionalisation of the political opposition in Transnistria began simultaneously in 2000 when a public movement called Renewal was established. It gradually started to gain the support of voters and political influence due to its financial resources, modern political strategies, criticism of the authorities, programme and activities meeting the people's need for change. Moreover, the movement had no real competitor because

10 Marcin Kosienkowski's conversation with Andrei Popov, executive director of Foreign Policy Association of Moldova, Chisinau, 15 August 2007.

11 Cf. Way (2011, p. 19).

12 Kosienkowski's interview, Chisinau, 8 July 2007. 
of Smirnov's reluctance to create a strong presidential party. Smirnov himself accepted Renewal's reinforcement due to several reasons. Among them were the party's strength based on the significant economic power of its sponsor - Sheriff, Smirnov's unwillingness to start confrontation with the economic elite that might hinder Transnistria's independence, his belief that Transnistrian legislature posed no serious threat to his power, and Renewal's approval of his interpretation of the Transnistrian conflict resolution.

In the 2000 parliamentary elections, Renewal took only 7 seats, although by 2005 it had already received 23 mandates out of 43 and had filled the post of the speaker of the Transnistrian legislative body, which was first given to Shevchuk and then to Kaminskiy in 2009. Sheriff's political representation, Renewal, was transformed into a political party in 2006, and in 2010 again won the parliamentary elections, gaining 26 seats or more, taking into account the independent MPs who supported Renewal. Kaminskiy held his post in parliament and became the leader of Renewal a few months earlier in July 2010, replacing Shevchuk, who finally left the party.

It is important that Renewal's parliamentary activity tried to limit the authority of the president. The first attempt was made in 2005 , a few months before the parliamentary elections, but turned out to be unsuccessful. The next attempt was undertaken in spring 2009. The struggle was fierce and only ended in 2011 in a compromise between Renewal and Smirnov, in which amendments (mainly about the post of prime minister introduced in Transnistria's history for the first time) were finally made to the Transnistrian constitution (Rodkiewicz 2011, pp. 13-14). It is important that Renewal participated in the 2011 presidential elections for the first time, nominating Kaminskiy, and in this way issuing the most serious challenge to Smirnov.

It ought to be underlined that Russia, being Transnistria's patron and guarantor of its existence, played a crucial role in the pluralisation of the quasi-state's politics. However, it should also be mentioned that Moscow's contribution came quite late. Although the Russian authorities noticed and watched over the institutionalisation of Renewal, they were initially wary of this political structure and still preferred to support Smirnov, associating him with political stability, predictability, and sufficient reliability. For example, when Renewal put forward a proposal for reform of the quasi-state's political system in favour of parliament in 2005 , Russia strongly opposed and helped to curb this initiative. Similarly, it successfully objected to the Renewal leader's, Shevchuk, participation in the 2006 presidential elections, which meant that Smirnov did not then have any serious political rival. 
Gradually, however, Renewal began to win authority in Russia's eyes. It is enough to say that since the end of 2007 Moscow has entrusted the supervision over the allocation of Russian assistance for Transnistria to a parliament controlled by Renewal, instead of the Smirnov group as it had been before; furthermore, Yedinaya Rossiya - a party associated with the president and later prime-minister of the Russian Federation, Vladimir Putin - signed a cooperation agreement with Renewal in November 2007. Russia also helped Renewal to parry Smirnov's attempt to increase his power in 2009 and facilitated the above-mentioned compromise concerning the reform of Transnistria's political system. Russia's growing support for Renewal was another serious factor which made Smirnov accept the existence of the political opposition in Transnistria.

More importantly, the cooperation between Russia and Renewal became so close that Moscow was publicly in favour of Kaminskiy's nomination for the presidential elections in December 2011. It was the first time that Russia had endorsed a politician other than Smirnov for the highest Transnistrian post.

On the one hand, Russia gave Kaminskiy full political, financial, marketing, and expert support. There were different billboards in Transnistria: some showed Renewal's leader together with Putin, who was very popular in the quasi-state, while others displayed the slogan: "Supported by Russia". It was supposed that it would increase Kaminskiy's chances of success, taking into account that Russia was recognised in Transnistria as its defender, breadwinner, and for many, homeland.

On the other hand, Russia started to put pressure on Smirnov not to take part in the presidential elections. Initially, they tried to persuade him softly. Sergey Naryshkin, the then head of Russia's president administration, simply advised Smirnov to resign when his (fourth) term ended (Gabuyev \& Solov'yev 2011). Smirnov had previously been declared "a monument", which should be honoured and respected, but it was added that he should not stay in power any longer. ${ }^{13}$ When it turned out that Smirnov was not going to give up, Russia intensified its pressure. The Transnistrian president's clan was accused of embezzling money, including Russian humanitarian assistance granted to Transnistria to support poor, ordinary people. Consequently, an action was brought by the Russian Investigation Committee against Smirnov's son Oleg. In addition, the Russian media, which was very popular in Transnistria, started to spread slanderous

13 "Mikhail Leont'yev: 'Smirnov - eto pamyatnik, a Rossii nuzhen novyy prezident Pridnestrov'ya' ", Lenta PMR, 3 June 2011, available at: http://tiras.ru/tema-dnja/24411-mihail-leontev-smirnov-eto-pamyatnik-a-rossii-nuzhen-novyy-prezident-pridnestrovya.html, accessed 10 December 2011. 
materials about Smirnov. For example, a programme called "Transnistria. The Deadline for the President" was shown on NTV just three days before the elections.

Although Russia's policy against Smirnov was perceived by many experts as clumsy, it certainly facilitated the pluralisation of internal politics in Transnistria. Moscow's activities contributed to holding the first competitive presidential elections in Transnistrian history. It also disoriented many of Smirnov's supporters, including bureaucrats who finally decided not to vote for the then president. Interestingly enough, it was most likely that after the first round of the elections, Moscow forced the powerful Transnistrian secret police not to oppose the results of the vote, and to convince Smirnov to accept his defeat and step down peacefully. Although later on, just before the second round, the head of the Transnistrian Ministry of State Security accused Shevchuk of being connected with foreign intelligence services, the British service in particular (Bubnovskiy 2011), his victory was quickly announced and his inauguration as the new president happened quickly. Non-interference by the secret police was probably provided again by Russia. This does not mean that Moscow held a direct interest in the democratisation of Transnistria. Rather it was something like a "managed democratisation" when only one "approved" candidate (Kaminskiy) was preferred to any other. In the end Russia managed to oust Smirnov but failed to "win" democratic elections which got out of control, with the irony being that Moscow indirectly contributed to Transnistria's democratisation, without meaning to.

Russia went against Smirnov and supported Kaminskiy because of at least four reasons. Firstly, Smirnov had been the main obstacle for any substantial dialogue between Tiraspol and Chisinau. Moscow always intended (but with various intensity) to play the role of a mediator in the conflict settlement trying both to gain everything in geopolitics, on the one hand, and to do it legitimately within the European context, on the other. It became particularly important for Russia in the context of the Meseberg process which was initiated by Russian president Dmitry Medvedev and German Chancellor Angela Merkel in June 2010. Some real progress in the Transnistrian conflict settlement was claimed to be a prerequisite for any substantial dialogue between the EU and Russia, also guaranteed by creating common institutions in the security sphere (Secrieru 2011, pp. 247-250; Devyatkov 2012).

Secondly, the European Union as well as Romania challenged Russian policy towards Moldova: despite the deployment of Russian troops on Moldovan territory, Chisinau is determined to move further towards closer integration with the EU (now in the form of political association) and Bucharest. A rational 
solution for Moscow in this case would be not to postpone the reintegration of Moldova because Transnistria could provide Russia with a share in the reunified state.

Thirdly, to support the gradual transformation of the Transnistrian political regime was important for Moscow in order to prevent any "colour revolution" in Tiraspol, which had become an option in 2009-2010 during the afore-mentioned constitutional crisis between the executive and legislative branches.

The fourth reason for Russia to change its approach towards Transnistria was the high price it paid to sponsor the Smirnov regime. Russian foreign policy resources were very limited, the state budget was overburdened by many social promises made by Vladimir Putin, the prime-minister and presidential nominee, as well as by subsidising volatile North Caucasus, and Abkhazia and South Ossetia being recognised as states by Russia in August 2008.

Moldova's contribution to Transnistria's pluralisation was indirect and far more insignificant than that of Russia; nevertheless, it also bore some importance. The point is that the policy of the former communist authorities of Moldova (20012009), which was mostly confrontational towards its breakaway region, was used by Smirnov to strengthen his position on the internal political scene. At this point, Transnistria's existence was really jeopardised. This fact significantly restricted the struggle for power between the local elites, which moreover, enforced unity against a common external enemy. This was the official reason that Shevchuk, the then leader of Renewal, offered to explain his decision not to challenge Smirnov in the 2006 presidential elections. ${ }^{14}$ Although the new Moldovan authorities which came to power in 2009, namely a coalition called the Alliance for European Integration, shared the views of the former government on the issue of the Transnistrian conflict settlement, it still changed its tactics toward Transnistria. In general, their policy was far more positive and included the (re)building and strengthening of Moldova-Transnistria ties, as well as winning over Transnistria's population and elites. Although it was realised with moderate commitment and brought few results, this approach finally made the relations between Moldova and Transnistria stable. This meant that external factors, such as Chisinau in

14 "Glavnyy prioritet Pridnestrov'ya - protivostoyaniye vneshnim ugrozam i sokhraneniye gosudarstva", Novyy Region 2, 29 December 2006, available at: http://www.nr2.ru/pmr/98414.html, accessed 23 December 2011. 
2006, deterring the power struggle in the quasi-state were eliminated and the political struggle in Transnistria could go on. ${ }^{15}$

Further advancement in political pluralisation in Transnistria, going beyond the bipolar Smirnov-Renewal political scene, was possible due to the fact that there was a politician - Shevchuk - who was associated by the majority of voters with a true renewal. Thanks to this asset he achieved what had seemed almost impossible - he beat Smirnov, an unchangeable strongman, and Kaminskiy, a politician backed by influential Russia, and became the winner of the 2011 Transnistrian presidential race.

Shevchuk beat Kaminskiy in the competition for the leadership over the renewal of Transnistria mainly because the former came to the elections as an outsider. On the one hand, he had not held any official post since 2009. Importantly, when stepping down from the post of Transnistria's parliament speaker, Shevchuk severely criticised the Smirnov regime for corruption, nepotism, neglect of ordinary people, infringements, and even sarcastically accused the president of an attempt to establish a monarchy or sultanate. ${ }^{16}$ It should be underlined that never before had such a senior official criticised Smirnov so harshly. Moreover, Shevchuk voluntarily resigned his office, which is very unusual in the post-Soviet area. Such behaviour signalled that he was a politician able to wage a decisive political struggle.

On the other hand, Shevchuk broke off ties with Renewal in 2010 and became even more of an outsider, as Renewal was an element of Transnistria's government due to its control over the parliament. However, he scored more points because of the fact that he was no longer connected to the party's sponsor, Sheriff, associated by many in Transnistria with bribery, smuggling, and other shady business. Many people were also afraid that if Renewal's candidate, Kaminskiy, became president, the party would only monopolise Transnistria's internal political scene to promote its own interests, and would forget about ordinary citizens and the idea of Transnistria's renewal.

When Shevchuk left his official post and Renewal, he did not entirely disappear from political life. Quite the opposite, together with his movement, the Revival of Transnistria, he started to struggle for change. Interestingly enough, as a person

15 For an overview of the Alliance of European Integration's policy on Transnistria, see Kosienkowski (2011, pp. 23-32).

16 Speech is available at: http://eshevchuk.ru/ru/content/\%C2\%ABprizyvayu-vsekh-obedinyatsya-daby-zashchitit-nashe-budushchee-gde-est-pravlenie-zakona-siln, accessed 15 January 2012. 
not involved with the authorities - unlike Kaminskiy, the speaker of parliament Shevchuk could act in a more free and uncompromising way, and speak about a broader scope of the problems, concerning the ruling elite as well. While Kaminskiy mainly paid attention to socioeconomic issues in his campaign, such as promising to provide people with warm flats, pensions, electricity, and new enterprises, Shevchuk focused on the idea of Transnistria's revival and the harsh criticism of the political establishment, accusing it of incompetence and bribery. It is also worth noting that due to the status of being an outsider, Shevchuk was excluded from the dirty political game waged between the two main candidates Smirnov and Kaminskiy. He mostly avoided the attacks of Moscow which targeted the president at the time. All these factors supported, or at least did not hinder his image of being an honest person, associated with the true renewal of Transnistria.

Furthermore, being a young politician (43 years old), Shevchuk was perceived as more dynamic, capable, and sincere than Kaminskiy (61 years old) when talking about change. Importantly, despite his age, he was already a very experienced politician. In 2000, at the age of 32 , he started his political career as a member of parliament and its deputy speaker; quite soon he became speaker and held the post between 2005-2009. What's more, he also established good working relations with the Russian authorities during that time. For example, his activity strongly contributed to the fact that Russia resumed its assistance to Transnistria in 2007. The suspension of Russian aid had resulted in the budget crisis and problems with paying pensions and salaries. It's most likely that Transnistrian voters had not forgotten about this, as well as all Shevchuk's other merits. ${ }^{17}$

\section{TRANSNISTRIA'S DEMOCRATISATION AND THE TRANSNISTRIAN CONFLICT SETTLEMENT: AN OUTLOOK}

Transnistria has undoubtedly experienced some democratic progress recently. This was completely obvious during the December 2011 presidential elections which were competitive for the first time in Transnistria's history. After the first round it became clear that Igor Smirnov had lost the elections; meanwhile, all the Transnistrian political players accepted the victory of Yevgeniy Shevchuk quite easily. Importantly, democratisation brought moderate political groups to power, and if interpreted according to Charles Tilly's theory (2007, pp. 13-14) as

17 For an analysis of Shevchuk's victory in the first round of the presidential elections, written from the Transnistrian point of view, see Ostanin (2011). 
a "movement towards broader, more equal, more protected, and more binding consultation" between the state and its citizens, democratisation is evidently growing in Transnistria. The authorities have started to consider people's needs to a much greater extent than compared to previous years. However, one should be cautious defining the political system in Tiraspol as democratic. Analytically it is more appropriate to speak about the pluralisation of the political system with the rise of two or even three power centres, and their competition has contributed substantially to the restart of public political life in the region. But people's participation in politics is still a subordinate priority. Moreover, it should be underlined that the perspectives of further democratisation of Transnistria are rather nebulous.

Even if Shevchuk's commitment to democratic values is true, he is not strong enough to introduce democratic reforms. Firstly, his real authority is limited by other highly influential political players, namely Renewal with parliament under its control, Smirnov's supporters, as well as Russia who constantly interferes in Transnistria's political processes. It is essential to note that they are not particularly interested in the further democratisation of Transnistria. So far, Renewal has been chiefly driven by the desire to take over power in the quasi-state. Sheriff, Renewal's sponsor and one of the main Transnistrian economic actors, is focused on its corporate interests, predominantly of an oligarchic nature, and also interferes into political affairs. In no way can supporters of the old regime be associated with democratic values, while Moscow was mainly concerned with ousting Smirnov. Secondly, despite his efforts, Shevchuk still does not have a strong, well-institutionalised political base with a large group of experienced politicians, unlike Renewal or Smirnov in the past. Thirdly, although the president is still the main figure in the political system, and despite the fact that the newly nominated prime minister, Petr Stepanov, has turned out to be a weak politician, Shevchuk's presidential prerogatives have been restricted when he lost the right to be the head of the government.

Moreover, Shevchuk seems to appreciate the political stabilisation in Transnistria, which excludes radical changes in the political sphere such as further democratisation. Soon after he won the presidential elections, he identified the unification of all Transnistrian political groups and citizens in order to create the proper conditions for Transnistria's revival, as one of his primary and most important tasks (Matveyev 2011). Furthermore, Shevchuk has ceased being so sharp-tongued as before - instead of harshly accusing the elites of corruption, he has started talking about joint efforts to create an effective state apparatus together 
with old but professional officials. ${ }^{18}$ To be sure, the new president has ousted many officials from office and later became successfully engaged in a political struggle with the opposition, trying to strengthen his leadership (Solov'yev 2012; Safonov 2012), although these removals were done quite peacefully without any witch-hunts, trials and imprisonments, while political confrontation has been despite the opposition's outcry - rather moderate.

It is important to point out that Russian and Transnistrian elites from outside the president's group support the stabilisation process in Transnistria because they are afraid that internal quarrels which are too harsh could undermine the continuous functioning of the quasi-state. Transnistrian elites have learnt how to deal with tense situations of conflicts of interest - they are ultimately resolved through compromises and bargaining. ${ }^{19}$ The case in point are the difficult negotiations that were probably held after the first round of the December 2011 elections, which ended with a compromise as well as the smooth nomination of the Transnistrian prime minister in late January 2012. Generally, it seems that stabilisation is given priority over other values. ${ }^{20}$ But it means that the achievement of pluralisation may be retained and democratic regress and a return to Smirnov's authoritarian period will not happen. ${ }^{21}$ If Shevchuk exacerbated the struggle for power in Transnistria and, as a result, enhanced its real authority, it would certainly not contribute positively to the process of the quasi-state's pluralisation.

Furthermore, the Transnistrian population, which actively supported Shevchuk and the idea of the quasi-state's renewal, mainly expects the improvement of their socioeconomic situation, which results in no pressure for further democratisation from below. The ideas of development and modernisation are more likely to be given priority and unite the Transnistrian people, elites and Russia, whereas the problem of democratisation is rather to be left aside.

Pluralisation of the internal political scene in Transnistria - mainly the arrival of the new Transnistrian president - has positively affected the process of the Transnistrian conflict settlement. On the one hand, all the local elites, including the

18 "Pridnestrov'ye zagnalo sebya v iskusstvennuyu izolyatsiyu ot vneshnego mira", Zerkalo nedeli, 20 January 2012, available at: http://zn.ua/POLITICS/evgeniy_shevchuk_pridnestrovie_zagnalo_sebya_v_iskusstvennuyu_izolyatsiyu_ot_vneshnego_mira-95987.html, accessed 28 January 2012.

19 Authors' interview with Vladislav Kulminski, Moldovan expert, via e-mail, 6 December 2011.

20 Authors' interview with Alyona Getmanchuk, director of Institute of World Policy (Kyiv), via e-mail, 2 December 2011.

21 Cf. Way (2011, pp. 24-26). 
new authorities, are in favour of the quasi-state's independence. Both Shevchuk ${ }^{22}$ and Renewal say that they follow the people's will - expressed in the referendum held in September 2006 - about Transnistria gaining independence and its subsequent accession to Russia. At present, any decision that runs counter to this position would mean political suicide for a Transnistrian politician and could destabilise the situation in the quasi-state. ${ }^{23}$ Another point is that democratisation has also raised the level of Transnistria's legitimisation, which has boosted its confidence in negotiations with Moldova.

On the other hand, Shevchuk has taken a more constructive policy than Smirnov did, and started to cooperate with all the participants of the official $5+2$ format negotiations; ${ }^{24}$ such an attitude is generally shared by Renewal (but it should be noted that the party has started to use developments related to Transnistrian-Moldovan relations to attack Shevchuk and undermine his political position). While the idea about Transnistrian statehood during the period of Smirnov's populist autocracy was based on quasi-ideological grounds, today's main political actors claim Transnistrian independence within the terms of "normal politics". It means that their positions, also towards the foreign issues, are negotiable and could be reinterpreted if actors' preferences are realised. The point is that the "Transnistrian idea" is originally a defensive mechanism against Moldovan nationalism in its 1990 os version (Chinn \& Roper 1995) and does not belong to the basic motivation of Transnistrian society which is, in fact, not so sure about its own identity as it seems to be. Moreover, due to the relatively free elections, the Transnistrian authorities, both the president and parliament, are more legitimate than the Smirnov regime was. This gives way to talks about conflict resolution, with the Transnistrian establishment truly representing the local population.

The more constructive position of Transnistria, first of all, means the development of cooperation and ties with the parent state. Importantly, this fits Moldova's policy towards Transnistria, at least in general terms. Economic and social problems have been brought into the foreground, taking into consideration people's hopes for the improvement of standards of living, plans for Transnistria's modernisation and business interests which mainly support Renewal and, to

22 “Ya nikomu ne sobirayus' sdavat' Pridnestrov'ye!", Komsomol'skaya prawda, 26 December 2011, available at: http://kp.ru/print/article/25810.5/2789897, accessed 1 January 2012.

23 Cf. Korobov (2011).

24. Along with the two opposing claimants, the so-called 5+2 format includes Russia, Ukraine, the Organization for Security and Co-operation in Europe, as well as the European Union and the United States participating as observers. 
some extent, Shevchuk. It is not surprising that the first steps the new president undertook were making it easier for Transnistrian citizens to cross the Transnistrian border and abolishing the $100 \%$ import duty on Moldovan goods brought to Transnistria. Whereas, before the first meeting between Yevgeniy Shevchuk and Moldovan prime minister Vlad Filat in late January 2012, the Transnistrian side had underlined that one of the key problems to be resolved was the facilitation of the external economic activity of Transnistrian companies connected with the resumption of full railway freight transportation through Transnistria, which had originally been halted in 2006 (Ivashkina \& Paterova 2012). The railway traffic was relaunched in April 2012 marking a progress in normalisation of Moldovan-Transnistrian relations. Other agreements on socioeconomic problems have either been concluded or are under negotiation.

Although Transnistria's policy is motivated by its desire to meet the internal demands and strengthen its statehood, it stabilises the situation in the region and enhances Transnistria-Moldova mutual confidence and security. It also helps create positive on-the-ground conditions, which can facilitate Moldova and Transnistria's negotiations on the final conflict settlement in the indefinite future. Obviously, progress also depends on Moldova's steps. Moldovan Prime Minister Filat proved ready for dialogue with Shevchuk and established good personal relations with the Transnistrian leader. However, Moldova generally finds it difficult to make palpable concessions in the Transnistrian conflict settlement. One of the reasons is that the Moldovan political scene, including the coalition government, is strongly divided and a party which would be in favour of concessions could be accused of high treason by the opposition or other members of the Moldovan government.

To sum up, although both Tiraspol, under the new government, and Chisinau, are not going to give up their opposing negotiation positions, normalisation of Transnistria-Moldova relations is undergoing and there is hope for further progress in the resolution of the Transnistrian problem. ${ }^{25}$

Finally, it should be noted that the process of Transnistria's democratisation could be fostered if the European Union provided development aid and enhanced economic relations with the quasi-state on condition that the latter promotes democratic values. Notably, Transnistria undoubtedly needs external assistance and better access to European markets to fight with its deep poverty and harsh economic crisis, as well as to modernise itself. Moreover, the Transnistrian

25 For the Moldovan perspective of the Transnistrian presidential elections' impact on the Transnistrian conflict settlement, see Litra (2011). 
population, the new authorities, and generally the elites seem to be more inclined than before to accept the possible offer. Political changes in Transnistria have clearly shown a desecuritisation move in the region, namely a shift from the priority of security to the balance of security and development. Development aid would be even more interesting for Transnistria if it exceeded Russia's assistance. Of course, even then, there is no guarantee that Transnistria would agree to the conditions or follow them, but it would be still worth trying. ${ }^{26}$

Importantly, further democratisation of Transnistria due to the process of its Europeanisation could contribute to the Transnistrian conflict settlement. Firstly, it could stimulate an open internal discussion about the future status of Transnistria; broader civil and political rights would ensure its free course. Secondly, the higher the level of democracy, the bigger the probability that agreements signed between Transnistria and Moldova will be kept, and that the united state will be viable. As Kálmán Mizsei - the former European Union Special Representative for the Republic of Moldova (2007-2011) - noticed while talking about the Transnistrian conflict settlement: "There is nothing better for peace than democracy". ${ }^{27}$ However, it should be emphasised that the problem of democratisation also concerns Transnistria's parent state - Moldova. The problem is that democracy in Moldova is still fragile. Under the rule of the Alliance for European Integration, the level of democracy in Moldova has admittedly improved, but only moderately, and not to such an extent as was expected.

\section{CONCLUSION}

Even the most stable regimes which exist within a permanent state of emergency, collapse when they evolve into inefficient, closed populist autocracies. In the post-Soviet space, including Transnistria, authoritative regimes have used the absence of the positive social capital in society to the full: people have lost their collective will, and due to socioeconomic problems, have preferred the absenteeist path. Under such circumstances, small social groups tend to instrumentalise any ideology or geopolitics in their favour and de facto privatise state structures. Nevertheless, the return of politics is unavoidable, particularly when a chain of democratisation movements is arising around the world. In Transnistria, the

\footnotetext{
26 See also Popescu \& Litra (2012).

27 Info-Prim Neo, 23 December 2011, available at: http://info-prim.md/?x=22\&y=43365, accessed 28 December 2011.
} 
regime of the populist autocracy was not able to meet people's basic needs and tried to take the edge off it through the ideologisation of politics. Like in Soviet times, the authorities had no opportunities to fulfil the programme they talked about: after the referendum of 2006 when Transnistrians voted for independence and unification with Russia, it became clear that promises could not be kept. Moreover, some factors like the institutionalisation of the opposition and Moscow's pressure have contributed substantially to the transformation of the regime.

But after the collapse of the authoritative regime various scenarios are possible, including those resulting in massive violence in society when there is no true institutional basis for democracy. Nevertheless, there is a scenario of a more stable development. The Transnistrian case is a demonstration of the latter: a newly elected leader has chosen the incorporation strategy towards other parts of the Transnistrian elite; and the main power centres seem to obey the rules of public political competition, following the priority of maintaining the integrated political system. But this fact is also a signal that the stability of the political system will be treated as a more important societal priority than democratisation itself. What Transnistria lacks now is stable socioeconomic development; the issue of political modernisation can be obscured in this context. With respect to conflict resolution, it should be noted that the pluralistic political system is obviously more open internally, and perhaps also externally. In the Transnistrian case, pluralisation is accompanied by socialisation into European political and social practices. It brings, of course, some chances of further progress in the resolution of the entrenched conflict in Moldova. The Transnistrian leader (not without the support of parliament), for example, quickly decided to abolish all the restrictions on trade operations with Moldova. Previously, the Transnistrian authorities had themselves provoked critical situations (like the Ilaşcu case ${ }^{28}$ for example) and tried to pass resolutions for good will, although it was just a put-on. Thanks to external mediators, negotiations within the $5+2$ format have been resumed. Yevgeniy Shevchuk does not oppose dialogue on the crucial political issues, but only after the "grassroots" problems, which are mainly of a socioeconomic

28 Ilie Ilaşcu is a Moldovan-born Romanian politician, famous for being sentenced to death together with his close associates by the Transnistrian government for alleged involvement in two murders and for actions which have been described as Moldovan state-sponsored terrorism by Transnistrian officials. In 2001 the "Ilaşcu group" was pardoned by the Transnistrian leader Igor Smirnov on the wave of a good start in negotiations with the newly elected Moldovan president Vladimir Voronin. 
character and crucial for the functioning of Transnistria, have been resolved. Moldovan as well as European positive steps would be very apt in this case.

Nevertheless, it should also be clarified that Shevchuk will be a very tough negotiator, pragmatic enough for making good steps forward, but also rational in defending the interests of the Transnistrian political community in today's very precarious circumstances. Until the Transnistrian people, companies and politicians get guarantees of their basic rights and security, as well as motivation for changing the status quo in the relations with Moldova, no breakthrough is possible in this regard. Any other "solutions" will be hindered in the region.

\section{REFERENCES:}

Bubnovskiy, M. (2011) "Antyufeyev zayavil o nalichii svyazey Shevchuka s zapadnymi posol'stvami", Novyy Region 2, 23 December, available at: http://www.nr2.ru/ policy/365162.html, accessed 23 December 2011.

Buzan, B., Wæver, O. \& de Wilde, J. (1998) Security: A New Framework for Analysis (Boulder, CO, Lynne Rienner Publishers).

Chinn, J. \& Roper, S. D. (1995) "Ethnic Mobilization and Reactive Nationalism: The Case of Moldova", Nationalities Papers, 23.

Crowther, W. (1991) "The Politics of Ethno-National Mobilization, Nationalism and Reform in Soviet Moldavia", The Russian Review, 2.

Devyatkov, A. (2012) "Russian Policy Toward Transnistria: Between Multilateralism and Marginalization", Problems of Post-Communism, 59, 3.

Freedom House (2001) "Freedom in the World: Transnistria [Moldova] (2002)", 18 December, available at: http://www.unhcr.org/refworld/docid/473c540919.html, accessed 8 January 2012.

Gabuyev, A. \& Solov'yev, V. (2011) "Igorya Smirnova slivayut bukval'no", Kommersant, 15 October.

ICG (2003) Moldova: no quick fix, Europe Report 147 (Chisinau \& Brussels, International Crisis Group), available at: http://www.crisisgroup.org/ /media/Files/europe/ Moldova\%20147.pdf, accessed 10 January 2012.

Ivashkina, I. \& Paterova, O. (2012) "W Dublin cherez Odessu", Kommersant, 25 January. Korobov, V. (2011) “Chego zhdat' ot Shevchuka na postu glavy Pridnestrov'ya", IA REX, 26 December, available at: http://www.iarex.ru/print/22461.html, accessed 26 December 2011.

Korobov, V. \& Byanov, G. (2006) Renewal of the Transnistria (Kherson, Naddnepryanochka). 
Kosienkowski, M. (2011) "The Alliance for European integration and the Transnistrian conflict settlement", Sprawy Narodowościowe-Nationalities Affairs, 38.

Litra, L. (2011) Regime Change in Transnistria: What Should Moldova Expect, Policy Brief 8, December (Chisinau, IDIS Viitorul).

Lynch, D. (2004) Engaging Eurasia's Separatist States: Unresolved Conflicts and De Facto States (Washington, D.C., United States Institute of Peace).

Matveyev, D. (2011) “Pervostepennymi zadachami na postu Prezidenta Pridnestrov'ya Shevchuk vidit ob"yedineniye politicheskikh sil i razvitiye ekonomiki", Novyy region 2, 26 December, available at: http://www.nr2.ru/pmr/365476.html, accessed 28 December 2011.

Memorial (1992) Large-scale and gross violations of human rights and the situation in the zone of armed conflict in and around the city of Bendery (June-July, 1992), Report, 11 September, available at: http://www.memo.ru/hr/hotpoints/moldavia/benderye.htm, accessed 10 January 2012.

Moshnyaga, V. (2002) "Pochemu tormozitsya razresheniye pridnestrovskogo konflikta?”, in Minorităţile naţionale şi relaţii interetnice: tradiţia europeană şi experienţa noilor democraţii pentru Moldova, vol. 1 (Iaşi, Pan Europe).

Obosnovaniye sozdaniya (1999) "Politiko-pravovoye obosnovaniye sozdaniya Pridnestrovskoy Moldavskoy Sotsialisticheskoy Respubliki. 2 sentyabrya 1990 g., in Nepriznannaya respublika. Ocherki, dokumenty, khronika, vol. 2 (Moskva, Rossiyskaya Akademiya Nauk).

Ostanin, V. (2011) "Shevchuk - pridnestrovskiy Obama", DNIESTER, 17 December, available at: http://dniester.ru/print/6228, accessed 1 January 2012.

Popescu, N. (2006) Democracy in Secessionism: Transnistria and Abkhazia's Domestic Policies, Policy Paper, August (Budapest, Central European University \& Open Society Institute), available at: http://www.policy.hu/news/NPopescu-PS/22, accessed 10 January 2012.

Popescu, N. \& Litra, L. (2012) Transnistria: A bottom-up solution, ECFR Policy Brief, available at: http://ecfr.eu/page/-/ECFR63_TRANSNISTRIA_BRIEF_AW.pdf, accessed 28 September 2012.

Protsyk, O. (2009) "Representation and Democracy in Eurasia's Unrecognized States: The Case of Transnistria", Post-Soviet Affairs, 25, 3.

Protsyk, O. (2012) "Secession and hybrid regime politics in Transnistria", Communist and Post-Communist Studies, 45.

Rodkiewicz, W. (ed.) (2011) Transnistrian Conflict after 20 Years (Warsaw \& Chisinau, Centre for Eastern Studies \& IDIS Viitorul), available at: http://www.osw.waw.pl/sites/ default/files/Transnistrian_Conflict_after_20_Years.pdf, accessed 1 December 2011. 
Safonov, A. (2012) "Rasstanovka politicheskikh silv PMR posle prezidentskikh vyborov 2011 goda", $A V A . M D$, 30 March, available at: http://ava.md/analytics-commentary/o15257rasstanovka-politicheskih-sil-v-pmr-posle-prezidentskih-viborov-2011-goda.html, accessed 15 April 2012.

Secrieru, S. (2011) "The Transnistrian conflict - new opportunities and old obstacles for trust building (2009-2010)", Southeast European and Black Sea Studies, 11, 3.

Smirnov, I. (2005) Zhit' na nashey zemle (Tiraspol, Liter).

Solov'yev, V. (2012) "Samyy chistyy kabinet”, Kommersant, 18 January.

Tilly, Ch. (2007) Democracy (Cambridge, Cambridge University Press).

Troebst, S. (2003) "We are Transnistrians! Post-Soviet identity management in the Dniester Valley", Ab Imperio, 1.

Viktorov, I. (2011) “Tematiku 'Razgovora s Prezidentom' opredelila zritel'skaya auditoriya: bor'ba s korruptsiyey, zloupotrebleniya chinovnikov, popytki raskola obshchestva", Olvia-press, 3 October, available at: http://www.olvia.idknet.com/ol43-10-11.htm, accessed 4 January 2012.

Way, L. (2011) “The Lessons of 1989”, Journal of Democracy, 22, 4.

The work was possible thanks to the support of the Russian Human Science Foundation (Project no. 13-33-01201). 